\title{
Developmental and Reproductive Performance of the Tobacco Thrips, Frankliniella fusca (Hinds) (Insecta: Thysanoptera), on Leaves of Nicotiana spp.
}

\author{
Shiro Nakao*, Chisako Chikamori \\ School of Life and Environmental Sciences, Kyoto Prefectural University, Kyoto, Japan \\ Email: ${ }^{*}$ nakao@kpu.ac.jp
}

Received 4 March 2014; revised 3 May 2014; accepted 17 May 2014

Copyright (C) 2014 by authors and Scientific Research Publishing Inc. This work is licensed under the Creative Commons Attribution International License (CC BY). http://creativecommons.org/licenses/by/4.0/

(c) (i) Open Access

\section{Abstract}

Tobacco thrips, Frankliniella fusca, which is a vector of Tospovirus, is a serious pest of tobacco, peanuts, and cotton in the United States. It was said that immigration of the adult thrips from weed hosts into crop fields is a cause of TSWV epidemy in the field. Recently this pest thrips was introduced into Japan. We investigated survival rate, developmental time, and fecundity of a Japanese strain of $F$. fusca on leaves of tobacco, peanut, and green bean at $18^{\circ} \mathrm{C}$. Thrips could not complete larval development on 3 Nicotiana species, $N$. tabacum, $N$. gossei, and N. rustica. On the other hand, survival rate from hatching to adult emergence on peanut and green bean is $78 \%$ and $86 \%$, respectively. A female adult thrips lived during about 25 days and deposited 101 eggs on green bean, but died within 10 days without ovipositing on Nicotiana spp. The tobacco is not a reproductive host plant that permits tobacco thrips to propagate, but an adult food source that is susceptible of TSWV.

\section{Keywords}

Tobacco, Thrips, Groundnut, Green Bean, Fecundity, Survival Rate

\section{Introduction}

Tomato spotted wilt virus (family Bunyauirdae, genus Tospovirus) causes economic losses to many cultivated crops. Tomato spotted wilt virus (TSWV) has a wide host range that includes several hundreds of plant species

"Corresponding author.

How to cite this paper: Nakao, S. and Chikamori, C. (2014) Developmental and Reproductive Performance of the Tobacco Thrips, Frankliniella fusca (Hinds) (Insecta: Thysanoptera), on Leaves of Nicotiana spp. Agricultural Sciences, 5, 555-559. http://dx.doi.org/10.4236/as.2014.56058 
over 20 families [1], and it is a serious economic threat to tobacco, Nicotiana tabacum L. and peanut, Arachis hypogaea L. [2]-[6].

TSWV is vectored exclusively by several thrips species, including the tobacco thrips, Frankliniella fusca, which are commonly observed on tobacco plants in USA [2] [3]. The virus must be acquired by thrips larva in which it multiplies and survives through the larval developmental stages. Mature adults became viruliferous and remain so throughout their lives [7]. Recently, the tobacco thrips was introduced into Japan [8].

The tobacco thrips is highly polyphagous and has been reported as the predominating thrips species on tobacco foliage in USA [2] [9], but few immature thrips have been collected on tobacco plants [2] [9]. Thus, it was suggested that there is little potential for secondary spread of the virus for populations on tobacco plants. They suppose that adults of tobacco thrips immigrate into tobacco fields from weed host in early season [1] [9] [10]. However, development and oviposition of the tobacco thrips on tobacco foliage have not been confirmed. Because $F$. fusca is a thrips species most likely to vector TSWV to a lot of susceptible crops, the development and the reproduction on not only adequate host plant species but also unsuitable host plant should be evaluated. Especially in crops fields where resources are provided in large areas, some may become source of viruliferous thrips, even if the crop plant is not good host for tobacco thrips. Biotic performance of the tobacco thrips has been investigated on a few crops, including cotton, Gossypium spp. [11] [12], peanut [13] [14], and tomato, Lycopersicon esculentum Mill. [14] and it is known that green bean is adequate to maintain population in laboratories [14]. Although pods of green bean were typically used to maintain culture of $F$. fusca [1] [15] [16], foliage is more available in time and space than pods in fields. Thus, we investigated suitability of tobacco plants as host plants of $F$. fusca in comparison with peanut and green bean, using leaf discs.

\section{Materials and Methods}

A thrips strain was originated from population on narcissus bulbs (Narcissus pseudonarcissus L.) produced in Fukushima Prefecture, Japan, in 2002 [17]. The strain was maintained on germinated broad bean seeds Vicia $f a b a$ L. (provided by International Fodder Industry as food for pigeons) which were placed on a moist Kimtowel ${ }^{\circledR}$ (produced by Cresia), in polystyrene containers $(97 \times 137 \times 50 \mathrm{~mm})$, as described in previous papers [17] [18]. The strain was kept at $22.5^{\circ} \mathrm{C}$ and $15 \mathrm{~L} 9 \mathrm{D}$.

Transparent plastic tubes (18 $\mathrm{mm}$ in diameter and $49 \mathrm{~mm}$ in length) with leaf discs were used as rearing cages for all experiments [17] [19]. Both ends of the tubes were covered with $\mathrm{M}$-film ${ }^{\circledR}$. Leaf disc (18 $\mathrm{mm}$ in diameter) was fixed between one end of the tube and the film. Each thrips in the cage was able to feed on surface of leaf discs $\left(\mathrm{ca} .2 .3 \mathrm{~cm}^{2}\right.$ ). Several female pupae were transferred from the stock culture to rearing cages with the surface of green bean Phaseolus vulgaris L. (cv. Tsurunashi-purasu-namame) leaf discs and reared under $18^{\circ} \mathrm{C}$ and 15L9D. Within 3 days after adult emergence, the females were allowed to mate with 2 - 5 day-old males and reared at the same photothermal condition. Number of mated females per cage was two, and they were transferred into fresh cages every day. Cages with leaf discs containing eggs laid by the mated females were kept at the same condition as the parent. Newly hatched larvae were placed in fresh cages with leaf discs of one of 5 plant species: Nicotiana tabacum L. (cv. BY-1), N. gossei Domin, N. rustica L., A. hypogaea L. (cv. Chibahandachi), and P. vulgaris (cv. Tsurunashi-purasu-namame), and reared under the same conditions. The larvae were transferred into fresh cages every 4 days, and number of individuals per cage was $2-6$ until emergence. Leaves were taken from young plant before flowering. Survival and developmental stages were recorded daily.

Some newly emerged female adults on $P$. vulgaris leaf discs were allowed to mate with newly emerged males. Each of the mated females was transferred to fresh cages with leaf discs of one of the 3 plants: N. tabacum, N. gossei, and P. vulgaris, every 2 days and reared individually throughout their lives under $18^{\circ} \mathrm{C}$ and 15L9D. Numbers of eggs deposited by them were recorded every day until death.

Since leaf discs of food plant dried up and deteriorate only a few days after supplying at higher temperature conditions, we surveyed rearing trials at $18^{\circ} \mathrm{C}$. It is known that $F$. fusca can complete immature development above $13^{\circ} \mathrm{C}$ [13] and deposit eggs above $18^{\circ} \mathrm{C}$ [17]. Tobacco plants in the fields are usually planted in April in the mainland of Japan, and mean daily air temperature in the early growing season is between $14^{\circ} \mathrm{C}-18^{\circ} \mathrm{C}$.

Statistical analyses were performed by PASW ${ }^{\circledR}$ Statistics Base ver. 18.0 [20] and the R statistical package version 2.15.3 [21].

\section{Results}

On three species of Nicotiana, F. fusca died in larval stage (Table 1). On two species of Leguminosae, the to- 
Table 1. Mortality and developmental period from hatching to adult emergence, and fecundity of $F$. fusca reared on leaf discs of five plant species under $18^{\circ} \mathrm{C}$ and 15L9D. Numbers in parentheses indicate sample size.

\begin{tabular}{|c|c|c|c|c|}
\hline \multirow{2}{*}{ Food plant } & \multirow{2}{*}{$\begin{array}{l}\% \text { mortality } \\
\text { in larval stage }\end{array}$} & \multicolumn{2}{|c|}{ Developmental period in days ${ }^{\mathrm{a}}$} & \multirow{2}{*}{$\begin{array}{l}\text { No. of eggs } \\
\text { per female }\end{array}$} \\
\hline & & Female & male & \\
\hline N. tabacum & $100(93)$ & - & - & $0(57)$ \\
\hline N. gossei & $100(68)$ & - & - & $0(46)$ \\
\hline N. rustica & $100(30)$ & - & - & not examined \\
\hline A. hypogaea & $21.9(32)$ & $17.1 \pm 1.1(7)$ & $16.6 \pm 1.0(18)$ & not examined \\
\hline P. vulgaris & $14.0(229)$ & $14.5 \pm 1.1(50)$ & $13.4 \pm 0.8(50)$ & $101.0 \pm 29.6(11)$ \\
\hline
\end{tabular}

${ }^{\mathrm{a}}$ Mean \pm S.D.; -: All died before pupation.

bacco thrips completed their development and eclosed as adults. Mortalities of immature stages between thrips on leaves of peanut and green bean were not significantly different from each other (Table 1: Fisher's exact probability test, $p=0.287$ ), and developmental time from hatching to adult eclosion was shorter for thrips on leaves of green bean than those on peanut (Table 1: Mann-Whitney's U test, $p<0.05$ for both sexes).

Female adults of F. fusca on N. tabacum and N. gossei died within 10 days without ovipositing. On the other hand, all females on green bean leaves deposited a lot of eggs (Table 1). Mean longevity of female adults on leaf discs of green been is 24.5 (S.D. $=8.1$ ) days, and mean preovipositional period is 2.9 (S.D. $=0.5)$ days, and deposited about 101 eggs during 20.5 (S.D. = 6.3) days (Table 1). Survival rate and the mean longevity were significantly different between adult females on green bean and those on each Nicotiana plant, respectively (logrank test using Cochran-Mantel-Haenszel method for survivorship curve, $p<0.001$ for each; Scheffe's multiple comparison for mean longevity, $p<0.05$ for each). Both mean longevities of the adults on two Nicotiana species (6.0 days on $N$. tabacum, and 6.1 days on $N$. gossei) and survival rate of them (Figure 1) were not significantly different from each other, respectively (log-rank test using Cochran-Mantel-Haenszel method for survivorship curve, $p>0.8$; Scheffe's multiple comparison for mean longevity, $p>0.9$ ).

\section{Discussion}

Although the tobacco thrips is an important pest on various cultivated plants, there is little information on mortality, development, and fecundity on different plants. Life history parameters of this thrips on cultivated crops have been recorded only on peanut and cotton [11]-[14]. On other plants including tomato and pepper, Capsicum annuum L., it has been mentioned that they can maintain population. In addition, cultures of $F$. fusca can be kept on green bean pods and whole green bean plant, [11] [12] [14]-[16]. However, no life history parameters on green bean have been reported. In the present study, no significant difference was found in survival rate between thrips on leaves of peanut and on those of green bean, and immature development time was shorter for thrips on green bean than that on peanut. Furthermore, this study indicated that a female deposited about a hundred eggs on green bean, and the number of eggs laid was about twice or thrice as those on peanut and cotton [13]. These results suggested that green bean is a suitable host plant of tobacco thrips.

Inter-specific difference on resistance of tobacco plant to pest insects is well known, and in general, wild tobacco plants express higher resistance than cultivated tobacco plant, N. tabacum [22] [23]. For example, mortalities of the greenhouse whitefly, Trialeuroides vaporariorum (Westwood), the sweet potato whitefly, Bemisia tabaci (Gennadius), and the green peach aphid, Myzus persicae (Sulzer) were significantly higher for nymphs on wild tobacco, N. gossei, than those on N. tabacum [22] [24]. The present study revealed that tobacco thrips cannot complete their larval development and does not oviposit on wild tobacco plants or on cultivated tobacco plant. These results showed that Nicotiana spp. is not good host plant for F. fusca.

Adult thrips of $F$. fusca died within 10 days on leaf discs of tobacco even at $18^{\circ} \mathrm{C}$, suggesting that in tobacco fields virus transmission to tobacco plants occurs after immigration of viruliferous adult thrips. Prior to invasion of F. fusca, twenty-two species of thysanopteran insects had been found on tobacco plants but only Thrips setosus Moulton successfully reproduces on the plant bodies of tobacco in the southwestern Japan, and the other thrips species incidentally come from weeds or adjacent crops where they increased explosively [25]. At present, there is no record of $F$. fusca on tobacco plants in Japan. The tobacco thrips might be also an incidental visitor to tobacco fields. 


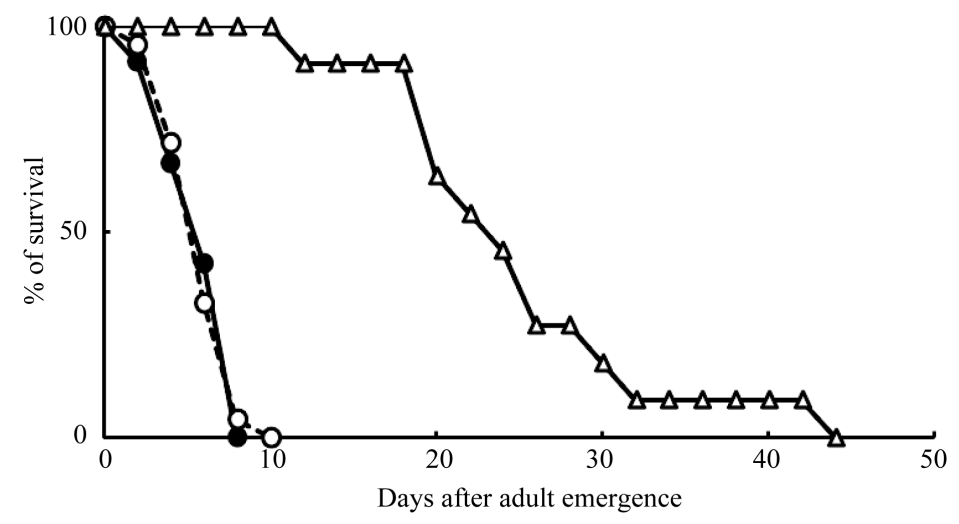

Figure 1. Survival rate of adult females of $F$. fusca on leaf discs of tobacco (closed circle: $\mathrm{n}=57$, on $N$. tabacum; open circle: $\mathrm{n}=46$, on $N$. gossei) and green bean (open triangle: $\mathrm{n}=11$, on P. vulgaris) under $18^{\circ} \mathrm{C}$ and 15L9D.

Our findings support that TSWV occurrences in tobacco fields mainly depend on immigration of macropterous adults of tobacco thrips produced on host plants other than tobacco in the spring after tobacco planting [16], because the tobacco thrips exhibits wing dimorphism and brachypters are not able to fly. Only brachypters of tobacco thrips occurred at moderate and lower temperature conditions below $18^{\circ} \mathrm{C}$ on green bean leaves, though it is known that higher temperatures induce production of macropterous females [17]. Thus, it is not likely that proportion of macropters of tobacco thrips in wild populations on weeds and winter crops increase in winter season. An understanding about environmental and genetic mechanisms regulating the macropter production in tobacco thrips seems to be the first step to decrease economic damages by TSWV and the tobacco thrips in tobacco production. Perhaps, incidence of macropters in spring population on weeds is of critical importance. Further studies are needed to clarify influences of food plants (quality and quantity of nutrient) and population densities on wing form determination in the tobacco thrips.

\section{Acknowledgements}

We wish to thank Mr Y. Narai (Shimane Agricultural Technology Center) and Dr A. Kato (Kyoto Prefectural University) for providing materials.

\section{References}

[1] Groves, R.L., Walgenbach, J.F., Moyer, J.W. and Kennedy, G.G. (2002) The Role of Weed Hosts and Tobacco Thrips, Frankliniella fusca, in the Epidemiology of Tomato Spotted Wilt Virus. Plant Disease, 86, 573-582. http://dx.doi.org/10.1094/PDIS.2002.86.6.573

[2] McPherson, R.M., Pappu, H.R. and Jones, D.C. (1999) Occurrence of Five Thrips Species on Flue-Cured Tobacco and Impact on Spotted Wilt Disease Incidence in Georgia. Plant Disease, 83, 765-767. http://dx.doi.org/10.1094/PDIS.1999.83.8.765

[3] McPherson, R.M. (2006) Incidence of Thrips and Tomato Spotted Wilt Tospovirus in Flue-Cured Tobacco Protected from Early Season Insect Pest Infestations. Journal of Economic Entomology, 99, 764-770. http://dx.doi.org/10.1603/0022-0493-99.3.764

[4] Barbour, J.D. and Brandenburg, R.L. (1994) Vernal Infusion of Thrips into North Carolina Peanut Fields. Journal of Economic Entomology, 87, 446-451.

[5] Wells, M.L., Culbreath, A.K., Todd, J.W., Csinos, A.S., Mandal, B. and McPherson, R.M. (2002) Dynamics of Spring Tobacco Thrips (Thysanoptera: Thripidae) Populations: Implications for Tomato Spotted Wilt Virus Management. Environmental Entomology, 31, 1282-1290. http://dx.doi.org/10.1603/0046-225X-31.6.1282

[6] Hurt, C.A., Brandenburg, R.L., Jordan, D.L., Kennedy, G.G. and Bailey, J.E. (2005) Management of Spotted Wilt Vectored by Frankliniella fusca in Virginia Market-Type Peanut. Journal of Economic Entomology, 98, 1435-1440. http://dx.doi.org/10.1603/0022-0493-98.5.1435

[7] Sims, K.R., Funderburk, J.E., Reits, S.R. and Boucias D.G. (2009) The Impact of a Parasitic Nematode, Thripinema fuscum, on the Feeding Behavior and Vector Competence of Frankliniella fusca. Entomologia Experimentalis et Ap- 
plicata, 132, 200-208. http://dx.doi.org/10.1111/j.1570-7458.2009.00884.x

[8] Nakao, S., Chikamori, C., Okajima, S., Narai, Y. and Murai, T. (2011) A New Record of the Tobacco Thrips Frankliniella fusca (Hinds) (Thysanoptera: Thripidae) from Japan. Applied Entomology and Zoology, 46, 131-134. http://dx.doi.org/10.1007/s13355-010-0020-z

[9] Eckel, C.S., Cho, K., Walgenbach, J.F., Kennedy, G.G. and Moyer, W. (1996) Variation in Thrips Species Composition in Field Crops and Implications for Tomato Spotted Wilt Epidemiology in North Carolina. Entomologia Experimentalis et Applicata, 78, 19-29. http://dx.doi.org/10.1111/j.1570-7458.1996.tb00761.x

[10] Groves, R.L., Walgenbach, J.F., Moyer, J.W. and Kennedy, G.G. (2003) Seasonal Dispersal Patterns of Frankliniella fusca (Thysanoptera: Thripidae) and Tomato Spotted Wilt Virus Occurrence in Central and Eastern North Carolina. Journal of Economic Entomology, 96, 1-11. http://dx.doi.org/10.1603/0022-0493-96.1.1

[11] Eddy, C.O. and Livingstone, E.M. (1931) Frankliniella fusca Hinds (Thrips) on Seedling Cotton. South Carolina Agricultural Experiment Station Bulletin, 271, 1-23.

[12] Watts, J.G. (1934) A Comparison of the Life Cycles of Frankliniella tritici (Fitch), F. fusca (Hinds) and Thrips tabaci Lind (Thysanoptera-Thripidae) in South Carolina. Journal of Economic Entomology, 27, 1158-1159.

[13] Lowry, V.K., Smith Jr., J.W. and Mitchell, F.L. (1992) Life-Fertility Tables for Frankliniella fusca (Hinds) and F. occidentalis (Pergande) (Thysanoptera: Thripidae) on Peanut. Annals of Entomological Society of America, 85, 744-754.

[14] Riley, D.G., Chitturi, A. and Sparks Jr., A.N. (2007) Does Natural Deposition of Pine Pollen Affect the Ovipositional Behavior of Frankliniella occidentalis and Frankliniella fusca? Entomologica Experimentalis et Applicata, 124, 133141. http://dx.doi.org/10.1111/j.1570-7458.2007.00561.x

[15] Groves, R.L., Walgenbach J.F., Moyer, J.W. and Kennedy, G.G. (2001) Overwintering of Frankliniella fusca (Thysanoptera: Thripidae) on Winter Annual Weeds Infected with Tomato Spotted Wilt Virus and Patterns of Virus Movement between Susceptible Weed Hosts. Phytopathology, 91, 891-899. http://dx.doi.org/10.1094/PHYTO.2001.91.9.891

[16] Morsello, S.C. and Kennedy, G.G. (2009) Spring Temperature and Precipitation Affect Tobacco Thrips, Frankliniella fusca, Population Growth and Tomato Spotted Wilt Virus Spread within Patches of the Winter Annual Weed Stellaria media. Entomologica Experimentalis et Applicata, 130, 138-148. http://dx.doi.org/10.1111/j.1570-7458.2008.00801.x

[17] Nakao, S. and Chikamori, C. (2013) Temperature-Dependent Wing Dimorphism in a Japanese Strain of Tobacco Thrips, Frankliniella fusca (Thysanoptera: Thripidae). Applied Entomology and Zoology, 48, 337-343. http://dx.doi.org/10.1007/s13355-013-0193-3

[18] Murai, T. and Loomans, A.J.M. (2001) Evaluation of an Improved Method for Mass-Rearing of Thrips and a Thrips Parasitoid. Entomologica Experimentalis et Applicata, 101, 281-289. http://dx.doi.org/10.1046/j.1570-7458.2001.00913.x

[19] Nakao, S. (1993) Effects of Temperature and Photoperiod on Wing form Determination and Reproduction of Thrips nigropilosus Uzel (Thysanoptera: Thripidae). Applied Entomology and Zoology, 28, 463-472.

[20] SPSS Inc. (2009) PASW® Statistics Base ver. 18.0.

[21] R Development Core Team (2013) The R Project for Statistical Computing. http://www.r-project.org/

[22] Buta, J.G., Lusby, W.R., Neal Jr., J.W., Waters, R.M. and Pittarelli, G.W. (1993) Sucrose Esters from Nicotiana gossei Active against the Greenhouse Whitefly Trialeuroides vaporariorum. Phytochemistry, 32, 859-864. http://dx.doi.org/10.1016/0031-9422(93)85220-L

[23] Harada, H., Takahashi, H., Matsuzaki, T. and Hagimori, M. (1996) Calcium Chloride as a Major Component Contributing to Aphid Resistance of Nicotiana benthamiana. Journal of Chemical Ecology, 22, 1579-1589. http://dx.doi.org/10.1007/BF02272399

[24] Neal Jr., J.W., Buta, J.G., Pittarelli, G.W., Lusby, W.R. and Bentz, J.-A. (1994) Novel Sucrose Esters from Nicotiana gossei: Effective Biorationals against Selected Horticultural Insect Pests. Journal of Economic Entomology, 87, 16001607.

[25] Koizumi, S. (1985) Studies on Thysanoptera Found on Tobacco Plants in the West Japan I. Species of Thysanoptera Infesting Tobacco Plants. Bulletin of Kagoshima Tobacco Experiment Station, 26, 55-74. 